\title{
Argyrophil cell hyperplasia and a carcinoid tumour in the stomach of a patient with sporadic Zollinger-Ellison syndrome
}

\author{
G E Feurle
}

\begin{abstract}
In the rat, hypergastrinaemia induced by drug treatment with omeprazole or potent $\mathbf{H}_{2}$ receptor antagonists leads to the development of gastric enterochromaffin-like cell carcinoids. In man, gastric carcinoids induced by hypergastrinaemia have been described only in patients with chronic atrophic gastritis type $\mathbf{A}$ and in patients with the multiple endocrine neoplasia syndrome type 1 . This patient with Zollinger-Ellison syndrome without gastric mucosal atrophy and without evidence of the multiple endocrine neoplasia syndrome developed an argyrophil gastric carcinoid tumour. This observation indicates that hypergastrinaemia in the sporadic Zollinger-Ellisonsyndrome may induce gastric carcinoids. (Gut 1994; 35: 275-277)
\end{abstract}

It is well known that gastrin has trophic effects on the acid producing part of the stomach.' In particular, the growth of enterochromaffin-like (ECL) cells is stimulated.' Chronic hypergastrinaemia in patients with type A chronic atrophic gastritis with or without pernicious anaemia, hypergastrinaemia in patients with gastrin producing tumours (Zollinger-Ellison syndrome), and hypergastrinaemia induced by prolonged inhibition of gastric acid secretion are associated with hyperplasia of the gastric ECL cells. ${ }^{2-5} \mathrm{~A}$ causal role of gastrin is indicated by the observation that the ECL cell hyperplasia regresses when hypergastrinaemia is abolished by antrectomy in patients with pernicious anaemia ${ }^{67}$ and by the observation that in the rat ECL cell hyperplasia can be prevented by a gastrin receptor anatagonist. ${ }^{8}$

In some patients, not only is hyperplasia of the ECL cells observed but ECL cell tumours also develop gastric carcinoids. ${ }^{3-5}$ These carcinoids have been observed in patients with long standing hypergastrinaemia with type A chronic atrophic gastritis and more rarely in patients with Zollinger-Ellison syndrome. ${ }^{3-5}$ It is believed that gastric ECL cell carcinoids in patients with the Zollinger-Ellison syndrome develop exclusively in those with the hereditary multiple endocrine neoplasia syndrome type 1 (MEN 1) and not in those with sporadic gastrinoma. ${ }^{9}$ It has therefore been suggested that carcinoids develop only when hypergastrinaemia is associated with either chronic inflammation and mucosal atrophy or when the genetic trait inherent in the MEN 1-syndrome is present. ${ }^{10}$ It is not clear whether hypergastrinaemia alone causes more than the induction of ECL cell hyperplasia and stimulates the growth of gastric carcinoids in man when neither mucosal atrophy nor the genetic trait is present. This question is of interest as it has been shown that long term acid suppression treatment leading to hypergastrinaemia induces both ECL cell hyperplasia and gastric ECL cell carcinoids ${ }^{11-15}$ in rats. Long term treatment with potent antisecretory drugs in man with inhibitors of the $\mathrm{K}^{+} \mathrm{H}^{+}$ATP ase and $\mathrm{H}_{2}$ receptor antagonists also leads to an increase in serum gastrin concentrations and to some degree in ECL cell hyperplasia. ${ }^{16}$ No carcinoids, however, have been reported in these patients to date. Recently, in a series of 200 patients with the Zollinger-Ellison syndrome, one patient without evidence of MEN 1 with a carcinoid tumour has been reported. ${ }^{17}$

I observed a patient with chronic hypergastrinaemia in the Zollinger-Ellison syndrome without evidence for MEN 1 and without atrophic gastritis who developed gastric argyrophil cell hyperplasia and a gastric carcinoid tumour.

\section{Case report}

When the patient was first examined at 38 years of age, she reported recurrent peptic ulcer disease for the previous six years. Family history showed no ulcer disease in the mother. The maternal grandfather had ulcers at young age but no further gastric disease: he was now 84 years old had no ulcer and was not taking ulcer medication. The father of the patient was unknown. On examination, a duodenal ulcer was present, basal gastric acid secretion was 34 $\mathrm{mmol} / \mathrm{h}$, stimulated gastric acid secretion 33 $\mathrm{mmol} / \mathrm{h}$. Serum gastrin concentration ${ }^{18}$ was 500 $\mathrm{pg} / \mathrm{ml}$ rising after an intravenous injection of secretin and after an infusion of calcium. Abdominal ultrasonography showed a tumour of the body of the pancreas and a questionable metastasis in the liver. The tumour was resected and gastrin concentrations returned to normal. Immunohistochemistry of the pancreatic tumour showed a positive reaction with a gastrin antibody. There was no reaction with antisera to somatostatin, insulin, or glucagon. One year later, ulcer symptoms recurred and the hepatic
Neuwied, University of Bonn, Germany Correspondence to: Dr G E Feurle, Stadtkrankenhaus, Marktstr 74,5450 Neuwied 1 Germany.

Accepted for publication 16 June 1993




Figure 1: Gastric mucosal carcinoid length $1.7 \mathrm{~mm}$ stained with an antibody to neuron specific enolase (original magnification $\times 38$ ).

metastasis was now clearly seen. Treatment with cimetidine and later ranitidine was resumed. Unfortunately, hepatic metastases continued to spread despite resection, treatment with octreotide, and selective perfusion of the hepatic artery with 4-epirubicin, streptozotocin, and 5fluorouracil. After one year of treatment, gastric acid secretion eight hours after $300 \mathrm{mg}$ ranitidine was $3.2 \mathrm{mmol} / \mathrm{h}$, later the dose of ranitidine was increased to $750 \mathrm{mg}$ daily to control symptoms. The patient never received omeprazole. At age 40 years her serum gastrin concentration was $2220 \mathrm{pg} / \mathrm{ml}$ and had risen to $34110 \mathrm{pg} / \mathrm{ml}$ at age 42 years. At this time hypercalcaemia with calcium serum concentrations up to $3.35 \mathrm{mmol} / \mathrm{l}$ developed. Plasma concentration of intact parathyroid hormone determined by radioimmunoassay $^{19}$ was $0.53 \mathrm{pmol} / 1$ (normal range 1.0 $7 \mathrm{pmol} / \mathrm{l})$. Plasma concentration of parathyroid hormone-related peptide (PTH rp) was $180 \cdot 3$ $\mathrm{pmol} / \mathrm{l}$ (normal range 5-21 pmol/1, determined with an antibody directed to the mid-region ${ }^{20}$ ).

Treatment with clodronate was added. At the same time, Cushing's syndrome developed with plasma cortisol values of $559 \mathrm{nmol} / 1$ and adrenocorticotrophic hormone (ACTH) plasma concentrations of $42 \mathrm{pmol} / \mathrm{l}$ (normal less than 20 $\mathrm{pmol} / \mathrm{l}$ ). Cortisol and ACTH plasma values were not suppressed by $8 \mathrm{mg}$ dexamethasone. Plasma prolactin and somatotropin values were in the normal range. The patient died of hepatic failure at age 43 years. Shortly before death, serum gastrin concentrations were $46400 \mathrm{pg} / \mathrm{ml}$.

At necropsy, the liver weighed $6.9 \mathrm{~kg}$, it was infiltrated by huge masses of partially necrotic metastases. The parathyroid glands were not detected and the stomach showed hyperplasia of the gastric glandular mucosa. A sample was removed from the oxyntic mucosa at random for microscopical examination. Light microscopy showed a $1.7 \mathrm{~mm}$ nodule on the surface of the

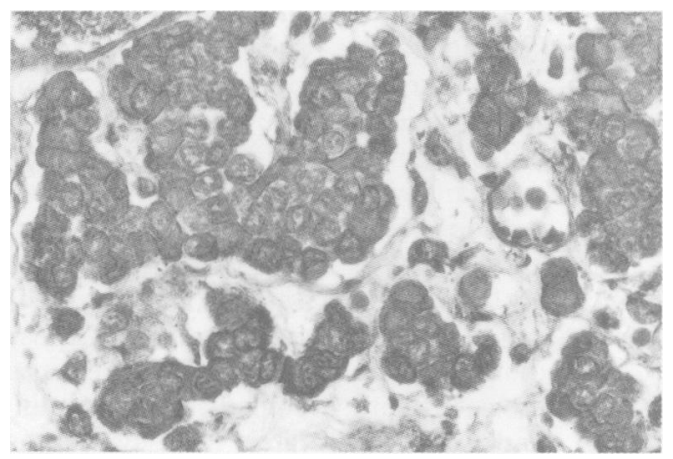
within the carcinoid of Figure 1 stained with the Grimelius silver method (original magnification $\times 212$ )

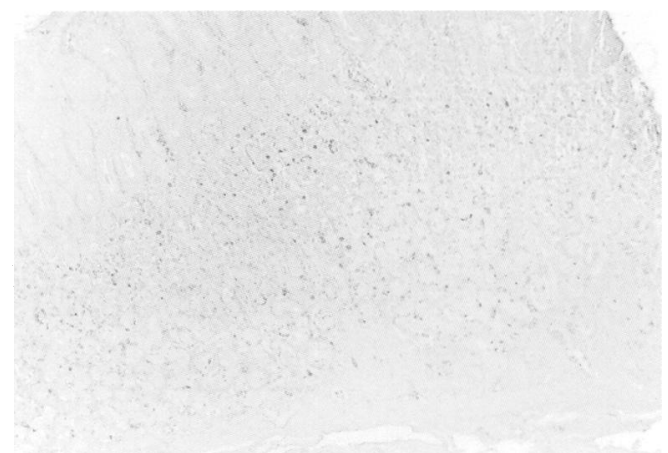

Figure 3: Diffuse argyrophil cell hyperplasia stained with the Grimelius silver method in the oxytic mucosa (original magnification $\times 170$ ).

fundic mucosa, not noticed macroscopically. Endocrine cells within this nodule stained with an antiserum to neuron - specific enolase (Fig 1). Silver impregnation ${ }^{21}$ showed an argyrophilic reaction of cuboidal cells situated in a trabecular fashion in the tumour (Fig 2). In the oxyntic mucosa, the argyrophilic cells showed a diffuse hyperplasia (Figs 3,4). No other form of argyrophil cell hyperplasia was observed. Classification was performed as proposed by Solcia et al. ${ }^{22}$ There was no gastric mucosal atrophy. The tumour did not stain with antisera to gastrin, somatostatin and pancreatic polypeptide. Electron microscopy was not performed. The hepatic metastases stained with antisera to gastrin and ACTH and western blot analysis showed the presence of PTHrp.

\section{Discussion}

This report shows argyrophil cell hyperplasia and an argyrophil carcinoid tumour in the oxyntic mucosa of a patient with sporadic Zollinger-Ellison syndrome. Gastric mucosal tumour with argyrophilic cells but without immunoreactivity with antisera against gastrin, somatostatin, and pancreatic polypeptide represent argyrophil carcinoids and are highly suggestive of an ECL cell tumour. ${ }^{23}$

The present observation indicates that gastric carcinoid tumours can occur without MEN 1 and without gastric mucosal inflammation and atrophy. The development of Cushing's syndrome cannot be taken as indicative for MEN 1, as ectopic production of ACTH by a gastrinoma is fairly common in the final phases of patients with a metastasising gastrinoma. ${ }^{24}$ Although

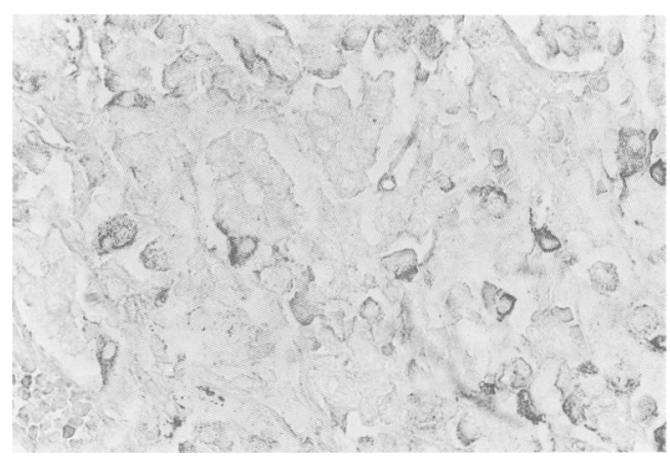

Figure 4: Higher magnification of the diffuse argyrophil cell hyperplasia in the oxyntic mucosa (original magnification $\times 360)$ 
hypercalcaemia was present in the last year of life, there was no evidence for hyperparathyroidism as the plasma parathyroid hormone concentration was suppressed. The hypercalcaemia was paraneoplastic and related to parathyroid hormone-related peptide produced by the gastrinoma.

Serum gastrin concentrations of the magnitude seen in the present patient are by far greater than those observed during long term treatment with omeprazole. ${ }^{16}$ However, a dose response relationship for the trophic of gastrin on the enterochromaffine-like cells has been described ${ }^{25}$ and the development of gastric carcinoids may be a function of the duration of the hypergastrinaemia. In a recent report on patients with pernicious anaemia, it was observed that carcinoids were present only in patients in whom a clinical diagnosis of pernicious anaemia had been made more than 10 years before endoscopy. ${ }^{25}$ The development of gastric carcinoids may therefore be a function of the magnitude of the serum gastrin concentration and the duration of hypergastrinaemia. If one assumes that hypergastrinaemia in our patient began at the time of first duodenal ulcer, then the duration of high serum gastrin concentrations would be approximately 10 years, the last three to four years with extremely high values. It seems possible that hypergastrinaemia of lesser degree over a longer period of time would also promote the development of gastric carcinoids. Whether the hypercalcaemia per se without the genetic defect of MEN 1 has contributed to tumour formation in our patient can only be speculation.

At any rate, patients with hypergastrinaemia, without atrophic gastritis and without MEN 1 can develop gastric carcinoid tumours. Patients under long term acid suppression therapy with hypergastrinaemia and argyrophil cell hyperplasia may need to be examined carefully for extended periods of time.

I thank Professor E Solcia, Pavia, for advice, Professor R Arnold, Marburg, for performing the argyrophil reaction, and Dr T Schilling, Heidelberg for the determination of PTH and PTH rp.

1 Hakanson R, Sundler F. Trophic effects of gastrin. Scand $\mathcal{F}$ Gastroenterol 1991; 180 (suppl): $130-6$.

2 Rubin W. Proliferation of endocrine-like (enterochromaffine) cells in atrophic gastric mucosa. Gastroenterology 1969; 57:

3 Borch K, Renvall H, Liedberg G. Gastric endocrine cell hyperplasia and carcinoid tumours in pernicious anemia. Gastroenterology 1985; 88: 638-48.

4 D'Adda T, Corleto V, Pilato FP, Baggi MT, Robutti F, Delle Fave G, Bordi C. Quantitative ultrastructure of endocrine cells of oxyntic mucosa in Zollinger-Ellison syndrome. Gastroenterology 1990; 99: 17-26.
5 Bordi C, Cocconi G, Togni R, Vezzadini P, Missale G. Gastric endocrine cell proliferation. Arch Pathol 1974; 98: 274-8.

6 Hirschowitz BI, Griffith J, Pellegrin D, Cummings OW. Rapid regression of enterochromaffinlike cell gastric carcinoids in pernicious anemia after antrectromy. Gastroenterology 1992; 102: 1409-18.

7 Kern SE, Yardley JH, Lazenby AJ, Boitnott JK, Yang VW, Bayless TM, Sitzmann JV. Reversal by antrectomy of endocrine cell hyperplasia in the gastric body in pernicious anemia: a morphometric study. Modern Pathology 1990; 3: $561-6$.

8 Eissele R, Patberg H, Koop H, Krack W, Lorenz W, McKnight AT, Arnold R. Effect of gastrin receptor McKnight AT, Arnold R. Effect of gastrin receptor blockade on endocrine cells in rate

9 Solcia E, Capella C, Fiocca R, Rindi G, Rosai J. Gastric argyrophil carcinoidosis in patients with Zollinger-Ellison syndrome due to type 1 multiple endocrine neoplasia. $A m \mathfrak{F}$ Surg Pathol 1990; 14: 503-13.

10 Solcia E, Capella C, Sessa F, Rindi G, Cornaggia M, Riva C, Villani $L$. Gastric carcinoids and related endocrine growths. Digestion 1986; 35: 3-22.

11 Ekman L, Hansson E, Havu N, Carlsson E, Lundberg G. Toxicological studies on omeprazole. Scand f Gastroenterol $1985 ; 20$ (suppl): 108, 53-69.

12 Brittain RT, Jack D, Reeves JJ, Stables R. Pharmacological basis for the induction of gastric carcinoid tumours in the rat by loxtidine, an unsurmountable histamine $\mathrm{H}_{2}$ receptor by loxtidine, an unsurmountable histamine 1 .

13 Poynter D, Selway SAM, Papworth SA, Riches SR. Changes in the gastric mucosa of the mouse associated with long lasting unsurmountable histamine $\mathrm{H}_{2}$ blockade. Gut 1986 27: $1338-46$.

14 Ryberg B, Bishop AE, Bloom SR, Carlsson E, Hakanson R, Larsson H, Mattsson H, Polak JM, Sundler F. Omeprazole and ranitidine, antisecretagogues with different modes of action, are equally effective in causing hyperplasia of enterochromaffin-like cells in rat stomach. Regul Pep 1989; 25: $235-46$.

15 Tielemans Y, Hakanson R, Sundler F, Willems G; Proliferation of enterochromaffinlike cells in omeprazole-treated hypergastrinemic rats. Gastroenterology 1989; 96: 723-9.

16 Lamberts R, Creutzfeldt W, Stöckmann F, Jacubaschke U, Maas S, Brunner G. Long-term omeprazole treatment in man: Effects on gastric endocrine cell populations. Digestion man: Effects on gastr.

17 Jensen RT. Gastrinoma as a model for prolonged hypergastremia in the human. In: Walsh JM ed. Gastrin. New York: Raven Press 1993: 373-93.

18 Feurle GE, Menzel J, Klempa I. Contribution of the antrum and duodenum to circulating forms of gastrin in the dog Regul Pept 1983; 7: 127-35

19 Blind E, Schmidt-Gayk H, Schlarla S. Flentje D, Fischer S, Göhring U, Hitzler W. Two-site assay of intact parathyroid homone in the investigation of primary hyperparathyroidism and other disorders of calcium metabolism compared with a midregion assay. $\mathcal{F}$ Clin Endocrin Metab 1988; 67: 353-60.

20 Blind E, Raue F, Götzmann J, Schmidt-Gayk H, Kohl B Ziegler R. Circulating levels of midregional parathyroid Ziegler $\mathbf{R}$. Circulating levels of midregional parathyroid hormone-related protein in hyper

21 Grimelius L. The argyrophil reaction in islet cells of adult human pancreas studied with a new silver nitrate procedure. Acta Soc Med Upsal 1968; 73: 271-4.

22 Solcia E, Bordi C, Creutzfeldt W, Dayal Y, Dayan AD Falkmer S, Grimelius L, Havu N. Histopathological classification of nonantral gastric endocrine growths in man. Digestion 1988; 41: 185-200.

23 Solcia E, Capella C, Buffa R, Rindi G, Fiocca R, Tenti P. The endocrine system of the gut in health and disease. Ital $\mathcal{F}$ Gastroenterol 1988; 20: 335-43.

24 Maton PN, Gardner JD, Jensen RT. Cushing's syndrome patients with the Zollinger-Ellison Syndrome. N Englf Med 1986; 315: 1-5.

25 Brenna E, Waldum HL. Trophic effect of gastrin on the enterochromaffine-like cells of the rat stomach: establishment of a dose response relationship. Gut 1992; 33: 1303-6.

26 Sjöblom SM, Sipponen P, Karonen SL, Järvinen HJ. Argyrophil cell hyperplasia and carcinoid tumours in oxyntic mucosa of the stomach. Dependence on duration of pernicious anaemia. Europ foumal of Gastroenterology and Hepatology 1991; 3: 153-7. 